\title{
Identification of Six Type III Effector Genes with the PIP Box in Xanthomonas campestris pv. campestris and Five of Them Contribute Individually to Full Pathogenicity
}

\author{
Wei Jiang, ${ }^{1}$ Bo-Le Jiang, ${ }^{1}$ Rong-Qi Xu, ${ }^{2}$ Jun-Ding Huang, ${ }^{1}$ Hong-Yu Wei, ${ }^{1}$ Guo-Feng Jiang, ${ }^{1}$ Wei-Jian Cen, \\ Jiao Liu, ${ }^{1}$ Ying-Ying Ge, ${ }^{1}$ Guang-Hua Li, ${ }^{1}$ Li-Li Su, ${ }^{1}$ Xiao-Hong Hang, ${ }^{1}$ Dong-Jie Tang, ${ }^{1}$ Guang-Tao Lu, ${ }^{1}$ \\ Jia-Xun Feng, ${ }^{1}$ Yong-Qiang He, ${ }^{1}$ and Ji-Liang Tang ${ }^{1}$ \\ ${ }^{1}$ Guangxi Key Laboratory of Subtropical Bioresources Conservation and Utilization, The Key Laboratory of Ministry \\ of Education for Microbial and Plant Genetic Engineering, and College of Life Science and Technology, Guangxi University, \\ 100 Daxue Road, Nanning, Guangxi 530004, China; ${ }^{2}$ Biotechnology Research Institute, Chinese Academy of Agricultural \\ Sciences, Beijing 100081, China
}

Submitted 3 April 2009. Accepted 7 June 2009.

Xanthomonas campestris pv. campestris is the pathogen of black rot of cruciferous plants. The pathogenicity of the pathogen depends on the type III secretion system (T3SS) that translocates directly effector proteins into plant cells, where they play important roles in the molecular interaction between the pathogen and its hosts. The T3SS of Xanthomonas spp. is encoded by a cluster of hypersensitive response and pathogenicity (hrp) genes. It has been demonstrated that the expression of $h r p$ genes and some type III secreted (T3S)effector genes is coactivated by the key $h r p$ regulatory protein HrpX. The regulation by HrpX can be mediated by the binding of $\mathrm{HrpX}$ protein to a cis-regulatory element named the plant-inducible promoter (PIP) box present in the promoter region of HrpX-regulated genes. A genome screen revealed that $X$. campestris pv. campestris 8004 possesses 56 predicted genes with the PIP box. Nine of these genes have been shown to encode T3S effectors, Hrp, and Hrp-associated proteins. In this study, we employed an established T3S effector translocation assay with the hypersensitive-reaction-inducing domain of $X$. campestris pv. campestris AvrBs1 as a reporter to characterize the remaining 47 genes with the PIP box and showed that 6 of them, designated as XopXccE1, XopXccP, XopXccQ, XopXccR1, XopXccLR, and AvrXccB, harbor a functional translocation signal in their N-terminal regions, indicating that they are T3S effectors of $X$. campestris pv. campestris. We provided evidence to demonstrate that all these effectors are expressed in an HrpX-dependent manner and their translocation into plant cells relies on the translocon protein $\mathrm{HrpF}$ and the chaperone HpaB. Mutational analyses demonstrated that all these effectors, except AvrXccB, are individually required for full virulence and growth of $X$. campestris pv. campestris in the host plant Chinese radish.

Numerous gram-negative phytopathogenic bacteria translocate so-called effector proteins directly into plant cells via a

Wei Jiang and Bo-Le Jiang contributed equally to this work.

Corresponding author: Ji-Liang Tang; telephone: +86-771-3239566; Fax: +86-771-3239413; E-mail: jltang@gxu.edu.cn

* The $\boldsymbol{e}$-Xtra logo stands for "electronic extra" and indicates that three supplemental tables are published online. type III secretion system (T3SS). The type III secreted (T3S) effectors inside the plant cells interact with plant substrates to activate or suppress plant defense signal transduction, resulting in elicitation of disease resistance or promotion of disease symptoms (Greenberg and Vinatzer 2003; Alfano and Collmer 2004; Mudgett 2005; Büttner and Bonas 2006; Grant et al. 2006). A given bacterial pathogen species or pathovar may develop its unique type of T3S effectors during the evolution of its pathogenicity, although homologues of some identified T3S effectors have been observed among different bacteria. As a first step toward understanding the molecular mechanisms by which T3S effectors function in the interaction between pathogens and plants, many research groups have been making efforts to identify T3S effectors from different important plant pathogens. However, the identification was limited for a long period of time to those effectors, termed avirulence (Avr) proteins, which can individually stimulate strong defense responses often associated with the hypersensitive reaction (HR) on some resistant host or nonhost plants. HR is a visible disease resistance phenomenon with a type of rapid, localized, and programmed cell death in the pathogen-infection tissues of plants (Alfano and Collmer 2004; Jones and Dangl 2006). This reaction is easily detected and has been used to identify a large number of Avr effector proteins from various pathogens. For most T3S effectors, loss of a single one did not affect pathogen virulence, or else its influence in pathogenicity could not be detected due to the absence of a sensitive detection method (Gürlebeck et al. 2006). Recently developed efficient identification methods and the availability of the genome sequences of major bacterial phytopathogens have facilitated the comprehensive identification of T3S effectors. Despite the fact that the authentic functional roles in pathogenicity of most T3S effectors remain to be further determined, large-scale identification of T3S effectors has been achieved in several pathogens such as Pseudomonas syringae pv. maculicola (Guttman et al. 2002), P. syringae pv. phaseolicola (Chang et al. 2005; Vencato et al. 2006), P. syringae pv. tomato (Petnicki-Ocwieja et al. 2002; Chang et al. 2005; Vinatzer et al. 2005; Schechter et al. 2006), Ralstonia solanacearum (Cunnac et al. 2004b), Xanthomonas campestris pv. vesicatoria (Roden et al. 2004), and $X$. oryzae pv. oryzae (Furutani et al. 2009). One of the strategies used to identify T3S effectors is the application of the HRinducing domains of Avr proteins. In general, the C-terminal domain of an Avr protein is sufficient to elicit an HR in a resis- 
tance host or nonhost plant that possesses a cognate resistance $(R)$ gene; T3S effectors have a modular structure, and their $\mathrm{N}$ terminal 50 to 100 amino acids harbor a functional signal to target proteins into plant cells (Mudgett et al. 2000; Guttman and Greenberg 2001; Greenberg and Vinatzer 2003; Schechter et al 2004). A number of T3S effectors have been successfully identified from $P$. syringae pv. maculicola and $X$. campestris pv. vesicatoria by using the $\mathrm{HR}$-inducing $\mathrm{C}$-terminal domain of AvrRpt2, AvrBs2, or AvrBs3 as a reporter (Guttman et al. 2002; Noël et al. 2003; Roden et al. 2004).

It is well known that the expression of T3SS-encoding genes and most T3S-effector genes is repressed in rich media and induced in plant tissues or in minimal media. In Xanthomonas spp., the T3SS is encoded by a cluster of hypersensitive response and pathogenicity ( $h r p$ ) genes consisting of at least six hrp operons (Arlat et al. 1991; Bonas et al. 1991). The expression of the hrp operons is activated by the key hrp regulatory proteins HrpG and HrpX. HrpG is a member of the OmpR family of two-component signal transduction response regulators and $\mathrm{HrpX}$ is an AraC-type transcriptional regulator. HrpG and HrpX form a regulatory cascade, in which HrpG regulates the expression of $h r p X$ and HrpX then regulates the expression of downstream hrp operons and some T3S-effector genes (Wengelnik and Bonas 1996; Wengelnik et al. 1996; Huang et al. 2009). It has been demonstrated that the regulation by HrpX in Xanthomonas spp. could be mediated by the binding of HrpX protein to a cis-regulatory element named the plant-inducible promoter (PIP) box (discussed below), present in the promoter region of HrpX-regulated genes (Fenselau and Bonas 1995; Tsuge et al. 2005; Koebnik et al. 2006). Such a regulation mode also exists in $R$. solanacearum (Cunnac et al. 2004a).

$X$. campestris pv. campestris is the causal agent of black rot disease of cruciferous plants. The pathogen infects almost all members of the crucifer family (Brassicaceae), including important vegetables such as broccoli, Brussels sprouts, cabbage, cauliflower, kale, mustard, and radish; the major oil crop rape; as well as the model plant Arabidopsis thaliana (Alvarez 2000). After determination of the whole-genome sequence of the $X$. campestris pv. campestris 8004 (Qian et al. 2005), we have made an effort to identify T3S effectors from the pathogen and have recently reported two such effectors discovered by translocation assay using the HR-inducing domain of the Avr protein AvrBs1 from X. campestris pv. campestris as a reporter (Jiang et al. 2008; Xu et al. 2008). Bioinformatics analysis revealed that the genome of the $X$. campestris pv. campestris 8004 possesses 56 predicted genes with the PIP box. In this work, we employed the previously established translocation assay to characterize these genes and showed that six of them are T3S effectors of $X$. campestris pv. campestris. We also demonstrated that five of the T3S effectors are individually required for full virulence and growth of the pathogen in the host plant Chinese radish.

\section{RESULTS}

\section{Fifty-six predicted genes with the PIP box present} in the genome of the $X$. campestris pv. campestris 8004.

A survey of the genomic sequence of the $X$. campestris pv. campestris 8004 (Qian et al. 2005) for the presence of the typical motif of the PIP box, TTCGB-N ${ }_{15}$-TTCGB (B refers to the base C, G, or T but not A) (Cunnac et al. 2004a; Koebnik et al. 2006), revealed that 56 predicted genes contain such a motif within the upstream sequence of their putative translational start codons. Among these genes, six are hrp, hrp-conserved ( $h r c$ ), or $h r p$-associated (hpa) genes; that is, XC_3001 (hpa2), XC_3002 (hpal), XC_3011 (hrpBl), XC_3012 (hrcU), XC_3015 (hrcQ), and XC_3019 (hrpD5). These hrp/hrc/hpa genes do not encode T3S effectors and their function has been studied in some detail. Thus, they were excluded for further study in this work. In addition, three of the PIP-box-containing genes have already been demonstrated to encode T3S effectors acting as Avr proteins; that is, $X C_{-} 0052$ ( $\left.a v r B s 2\right)$ (Ignatov et al. 2002), XC_2004 (avrXccC) (Castañeda et al. 2005), and $X C \_2602$ (avrXccE1) (He et al. 2007). The remaining 47 genes with the PIP box were taken as candidates for identification of novel T3S effectors of $X$. campestris pv. campestris in this study. One of the candidates, named XC_3802, was annotated to encode an Avr protein (AvrXccB) (da Silva et al. 2002; Qian et al. 2005); however, no experimental evidence has been reported to show that it is an Avr protein or T3S-effector.

\section{Identification of six T3S-effector genes \\ from the PIP box-containing genes by translocation assay.}

Our previous work has demonstrated that the Avr protein AvrBs1 of $X$. campestris pv. campestris 8004 is responsible for the pathogen to induce an HR on pepper cv. ECW-10R in a T3SS-dependent manner (Xu et al. 2008). The avrBs1-deletion mutant harboring $a v r B s 1_{59-445}$, an $a v r B s 1$-derivative lacking the first 58 codons that encode amino acids for a functional translocation signal, cannot elicit an HR. However, a fragment coding for a functional translocation signal from another T3S effector fused to the $5^{\prime}$ end of $a v r B s 1_{59-445}$ in an in-frame manner can target the fusion protein into plant cells and elicit an $\mathrm{HR}$ in the pepper ECW-10R (Xu et al. 2008). To investigate whether any products of the above 47 candidate open reading frames (ORF) encode T3S effectors, we determined the functionality to target proteins into plant cells of their N-terminal domains by using the HR-inducing domain AvrBs $1_{59-445}$ as a reporter. To facilitate the determination, a reporter plasmid, named pJAG, was constructed, which contains the Plac promoter upstream of the multiple cloning sites and $a v r B s 1_{59-445}$ fused with the $5^{\prime}$ end of $3 \times$ FLAG (details provided below). A DNA fragment harboring the putative promoter and T3S signal-encoding sequence from each of the 47 candidate genes was cloned into the plasmid pJAG, giving an in-frame fusion between the N-terminal amino acids of a candidate and the AvrBs $1_{59-445}$.

All of the obtained 47 recombinant plasmids were introduced into the avrBs 1 -deletion mutant strain $8004 \Delta$ avrBs 1 (Xu et al. 2008) by triparental conjugation. The resulting transconjugant strains were then tested for HR induction on the leaves of pepper cv. ECW-10R. The results showed that, $24 \mathrm{~h}$ after inoculation, the mutant strain $8004 \Delta$ avrBs1 carrying the recombinant plasmid pJAG2994, pJAG2995, pJAG3160, pJAG3177, pJAG3802, or pJAG4273, which carried an inframe fusion between AvrBs1 $1_{59-445}$ and the N-terminal amino acids of the ORF XC_2994, XC_2995, XC_3160, XC_3177, $X C \_3802$, or $X C_{-} 4273$, could stimulate a typical HR on pepper ECW-10R (Fig. 1A), whereas $8004 \Delta$ avrBs1 harboring any of the other 41 recombinant plasmids could not (data not shown). These results revealed that the $\mathrm{N}$-terminal regions of the proteins encoded by the genes XC_2994, XC_2995, $X C \_3160, X C \_3177, X C \_3802$, and $X C \_4273$ possess a translocation signal with the functionality to target proteins into plant cells, suggesting that these proteins are T3S effectors.

\section{Translocation of the six T3S effectors relies on the translocon protein HrpF and the chaperone HpaB.}

The HrpF of $X$. campestris is a putative T3SS translocon protein required for the translocation of $\mathrm{T} 3 \mathrm{~S}$ effectors across the plant plasma membrane (Büttner et al. 2002; Meyer et al. 2006), whereas HpaB is a T3SS chaperone crucial for the efficient translocation of T3S-effector proteins (Büttner et al., 2004). To investigate whether $\mathrm{HrpF}$ and $\mathrm{HpaB}$ are involved in 


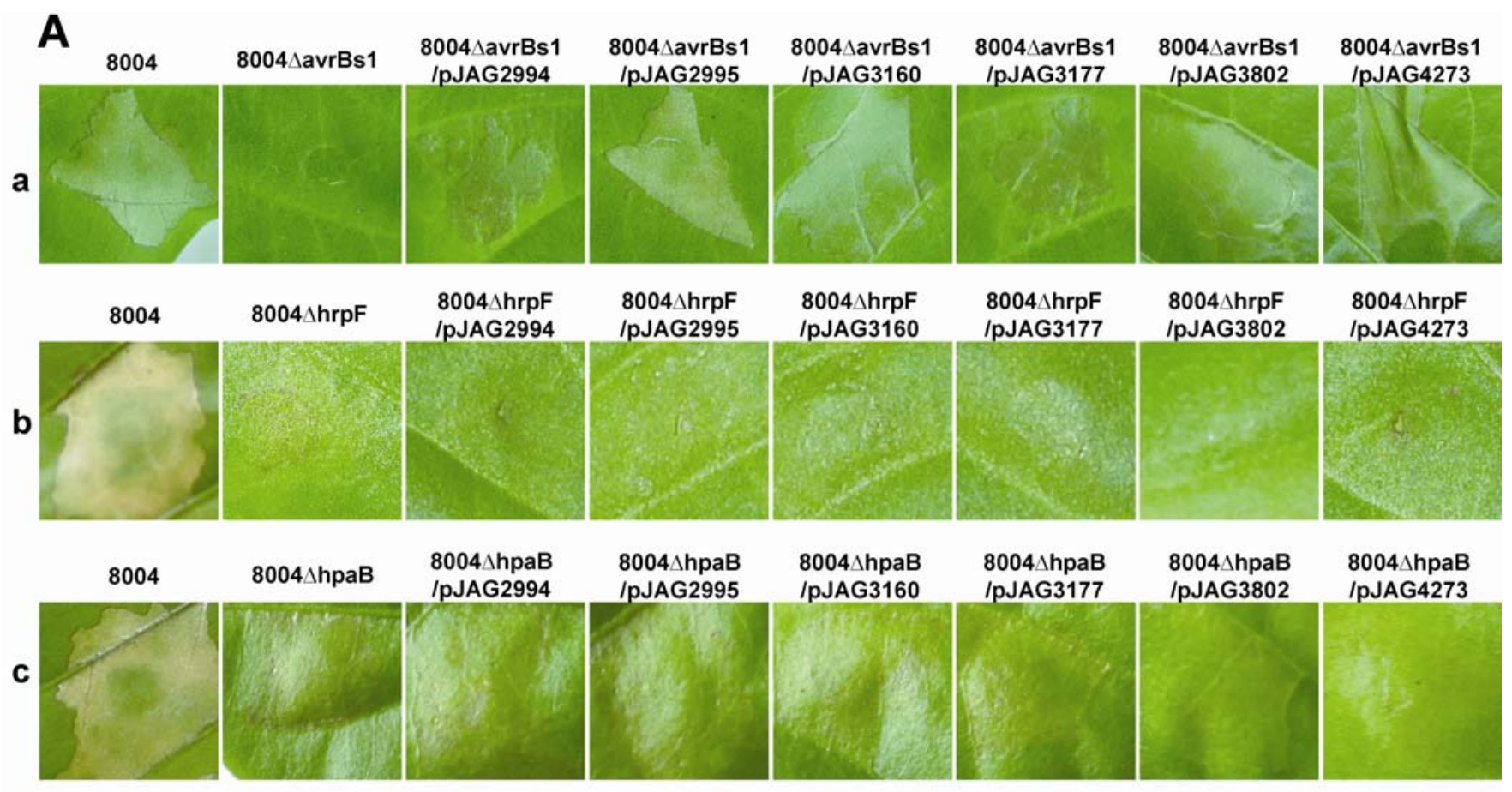

B
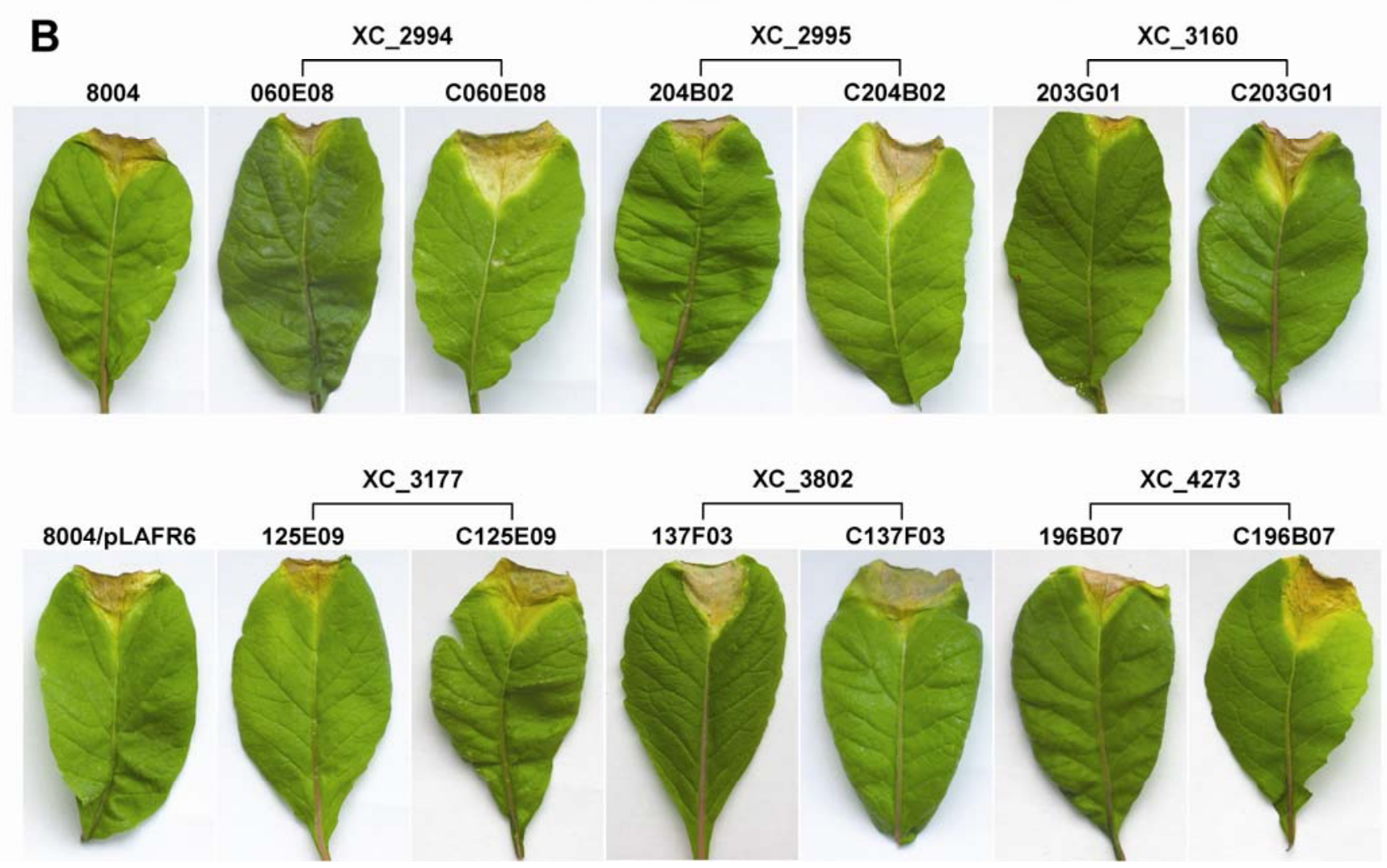

Fig. 1. Analyses of hypersensitive reaction (HR) induction and virulence of Xanthomonas campestris pv. campestris strains. A, HR-induction analysis on the leaves of pepper ECW-10R (Capsicum annuum cv. ECW-10R) carrying the resistance gene Bs1. The wild-type 8004 induced HR symptoms but the avrBs1deletion mutant strain $8004 \Delta$ avrBs1, the hypersensitive response and pathogenicity ( $h r p$ ) $F$-deletion mutant strain $8004 \Delta$ hrpF, and the $h p a B$-integration

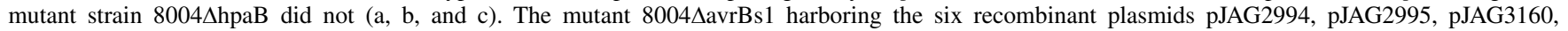
pJAG3177, pJAG3802, and pJAG4273, which carried an in-frame fusion between AvrBs $1_{59-445}$ and the N-terminal amino acids of the open reading frames (ORF) XC_2994, XC_2995, XC_3160, XC_3177, XC_3802, or XC_4273, respectively, could stimulate typical HR symptoms (a); however, the mutants $8004 \Delta \mathrm{hrpF}$ and $8004 \Delta \mathrm{hpaB}$ harboring the same plasmids could not (b and c), suggesting that the ORF XC_2994, XC_2995, XC_3160, XC_3177, XC_3802, and XC_4273 encode type III secreted (T3S)-effector proteins and the translocation of which into plant cells relies on the T3S translocon HrpF and the T3S chaperone HpaB. The photographs were taken $24 \mathrm{~h}$ (a) and $72 \mathrm{~h}$ (b and c) postinoculation. B, Virulence analysis on the leaves of Chinese radish (Raphanus sativus var. radiculus) cv. Manshenhong. The mutants 060E08, 204B02, 203G01, 125E09, and 196B07 but not the mutant 137F03 showed reduced black rot disease symptoms compared with the wild-type 8004, and the complemented strains (C060E08, C204B02, C203G01, C125E09, C137F03, and C196B07) and the wild type harboring the vector plasmid pLAFR6 (8004/pLAFR6) showed wild-type disease symptoms. The photographs were taken on day 9 postinoculation. 
the secretion of the identified six T3S effectors, the recombinant plasmids pJAG2994, pJAG2995, pJAG3160, pJAG3177, pJAG3802, and pJAG4273 were also introduced by triparental conjugation into the $h r p F$-deletion mutant strain $8004 \Delta \mathrm{hrpF}$ and the $h p a B$-integration mutant strain $8004 \Delta$ hpaB. Transconjugant strains for each of the six recombinant plasmids were obtained and tested for HR production on pepper ECW-10R. At $72 \mathrm{~h}$ after inoculation, no visible HR was elicited by any of the transconjugant strains (Fig. 1A). These results suggest that the translocation of all six T3S effectors into plant cells relies on the T3SS translocon protein HrpF and the chaperone HpaB.

\section{Expression of the six T3S-effector genes is regulated by HrpG and HrpX.}

Although it has been demonstrated that the PIP box serves as a regulatory element and HrpX activates the expression of genes with the PIP box within their promoters via binding to the PIP box (discussed below), HrpX-independent PIP-box-containing promoters have been observed (Gürlebeck et al. 2006). To determine whether the expression of the six identified T3S-effector genes is regulated by $\mathrm{HrpX}$ and $\mathrm{HrpG}$, a promoter-reporting plasmid carrying the promoter region of each of the six effector genes fused with the promoterless $\beta$-glucuronidase (gus) gene was constructed and introduced into the wild-type strain 8004, the $h r p X$-deletion mutant $8004 \Delta \mathrm{hrpX}$, and the $h r p G$-deletion mutant $8004 \Delta \mathrm{hrpG}$ by triparental conjugation (details provided below). The GUS activities of the obtained reporter strains cultured in the minimal medium MMX (Daniels et al. 1984), in which expression of hrp genes is strongly induced (Wei et al. 2007b), and the rich medium NYG (Daniels et al. 1984) were then measured and compared. The results are presented in Table 1. When grown in MMX medium, each and every reporter of the six effector genes in the $h r p X$ or $h r p G$ mutation background produced significantly lower GUS activity than in the wild-type background ( $P=0.01$ by $t$ test). The GUS activity values produced by the reporters in the wild-type background are 4- to 72fold higher than those in the $h r p X$ or $h r p G$ mutation background (Table 1). All the reporter strains produced very feeble GUS activity when grown in NYG rich medium compared with those grown in MMX minimal medium (Table 1). These results demonstrate that the expression of XC_2994, XC_2995, XC_3160, $X C \_3177, X C \_3802$, and $X C \_4273$ is induced in MMX minimal medium and positively regulated by the $h r p$ regulators HrpX and HrpG.

\section{Five of the six identified T3S effectors are individually essential for full pathogenicity of $X$. campestris pv. campestris.}

In order to investigate the role of the identified T3S effectors in pathogenicity of $X$. campestris pv. campestris, we screened the mutant library of the $X$. campestris pv. campestris 8004, which was constructed by transposon Tn5gusA5 insertion mutagenesis in our laboratory (details provided below), for mutants of the six T3S-effector-coding genes. Mutants named 060E08, 204B02, 203G01, 125E09, 137F03, and 196B07, in which a Tn5gusA5 was inserted in each of the six T3S-effector-coding genes $X C \_2994, X C \_2995, X C \_3160, X C \_3177$, $X C_{-} 3802$, and $X C_{-} 4273$, respectively, were obtained. All of the mutants grew identically to the wild-type strain 8004 in NYG rich medium as well as MMX minimal medium (data not shown). The virulence of the mutants was tested on the host plant Chinese radish (Raphanus sativus var. radiculus) cv. Manshenhong by the leaf-clipping method (Dow et al. 2003). The results showed that five mutants (i.e., 060E08, 204B02, 203G01, 125E09, and 196B07) exhibited a significant reduction in virulence compared with the wild-type strain $(P=0.01$ by $t$-test), while the mutant 137F03 displayed the same virulence as the wild type (Fig. 1B). Ten days after inoculation, the mean lesion length of the disease symptoms caused by the mutants 060E08, 204B02, 203G01, 125E09, and 196B07 was only $8.2,8.2,4.5,9.4$, and $8.7 \mathrm{~mm}$, respectively, whereas the wild type caused a mean lesion length of $13.2 \mathrm{~mm}$ (Fig. 2A).

To validate whether the reduced virulence phenotype of the mutants was indeed caused by the transposon Tn 5 gusA 5 insertion disruption of the five corresponding T3S-effector-coding genes, a complemented strain for each of the mutants was constructed in this study by transferring a recombinant plasmid, in which an entire corresponding gene was cloned into the plasmid pLAFR6 (Huynh et al. 1989), into the corresponding mutant (details provided below). The virulence of the resulting complemented mutant strains was then examined. The results displayed that the mean lesion lengths caused by the complemented strains, the wild-type strain 8004, and the strain 8004 harboring the vector pLAFR6 alone were not significantly different ( $P=0.05$ by $t$ test) (Fig. $2 \mathrm{~A})$, suggesting that the virulence reduction of the five mutants was indeed initiated by the Tn5gusA5 insertion disruption of the corresponding T3S-effector-coding genes. Taken together, these results demonstrate that $X C \_2994, X C \_2995, X C \_3160, X C \_3177$, and $X C \_4273$ are essential for full virulence of $X$. campestris pv. campestris.

To evaluate the role of the T3S-effector genes in the growth of $X$. campestris pv. campestris in host plants, the bacterial populations of the mutants of the T3S-effector genes, the wildtype strain, and the complemented strains in the infected radish leaves were compared. The results showed that, besides the mutant strain 137F03 (the mutant of $X C_{-}$3802), the bacterial numbers of the other five mutants recovered from the infected leaves were significantly fewer $(P=0.01$ by $t$ test $)$ than that of the wild-type strain 4 days postinoculation and onward (Fig. 2B). There was no significant difference among the growth

Table 1. $\beta$-Glucuronidase (GUS) activities produced by the type III secreted (T3S)-effector promoter-gusA reporters under different genetic backgrounds in different growth conditions ${ }^{\mathrm{Z}}$

\begin{tabular}{lllllll}
\hline & \multicolumn{5}{c}{ GUS activities (mg/ml/min/OD 600$)$} \\
\cline { 2 - 7 } Strain & pLGUS2994 & pLGUS2995 & pLGUS3160 & pLGUS3177 & pLGUS3802 & pLGUS4273 \\
\hline $8004(\mathrm{~N})$ & $0.07 \pm 0.04 \mathrm{a}$ & $0.08 \pm 0.00 \mathrm{a}$ & $0.02 \pm 0.01 \mathrm{a}$ & $0.03 \pm 0.00 \mathrm{a}$ & $1.11 \pm 0.14 \mathrm{a}$ & $0.07 \pm 0.01 \mathrm{a}$ \\
$8004(\mathrm{M})$ & $1.07 \pm 0.12 \mathrm{~b}$ & $4.79 \pm 0.32 \mathrm{~b}$ & $0.90 \pm 0.09 \mathrm{~b}$ & $0.72 \pm 0.17 \mathrm{~b}$ & $10.27 \pm 0.83 \mathrm{~b}$ & $0.23 \pm 0.01 \mathrm{~b}$ \\
$8004 \Delta$ hrpG (M) & $0.08 \pm 0.02 \mathrm{a}$ & $0.67 \pm 0.18 \mathrm{a}$ & $0.03 \pm 0.01 \mathrm{a}$ & $0.01 \pm 0.01 \mathrm{a}$ & $0.62 \pm 0.03 \mathrm{a}$ & $0.05 \pm 0.01 \mathrm{a}$ \\
$8004 \Delta$ hrpX (M) & $0.05 \pm 0.03 \mathrm{a}$ & $0.69 \pm 0.08 \mathrm{a}$ & $0.04 \pm 0.01 \mathrm{a}$ & $0.04 \pm 0.03 \mathrm{a}$ & $0.65 \pm 0.04 \mathrm{a}$ & $0.04 \pm 0.01 \mathrm{a}$ \\
\hline
\end{tabular}

${ }^{2}$ The T3S-effector promoter-gusA reporters pLGUS2994, pLGUS2995, pLGUS3160, pLGUS3177, pLGUS3802, and pLGUS4273 were constructed by cloning the DNA fragments containing the promoter regions of the T3S-effector genes XC_2994, XC_2995, XC_3160, XC_3177, XC_3802, and XC_4273, respectively, into the reporter plasmid pLGUS which harbors the promoterless gusA gene. The T3S-effector promoter-gusA reporters were introduced into the wild-type 8004 , the hypersensitive response and pathogenicity $(h r p) G$ mutant $8004 \Delta \mathrm{hrpG}$, and the $h r p X$ mutant $8004 \Delta$ hrpX by triparental conjugation, and their GUS activities were detected by measurement of the optical density at $415 \mathrm{~nm}\left(\mathrm{OD}_{415}\right)$ using $\rho$-nitrophenyl- $\beta$-D-glucuronide as substrate after being grown in NYG (N) (Daniels et al. 1984) for $16 \mathrm{~h}$ or MMX (M) (Daniels et al. 1984) for $24 \mathrm{~h}$. The different letters in each data column indicate significant differences at $P=0.01$ by $t$ test. Values given are the means and standard deviations of triplicate measurements. Data presented were from a representative experiment and similar results were obtained in two other independent experiments. 


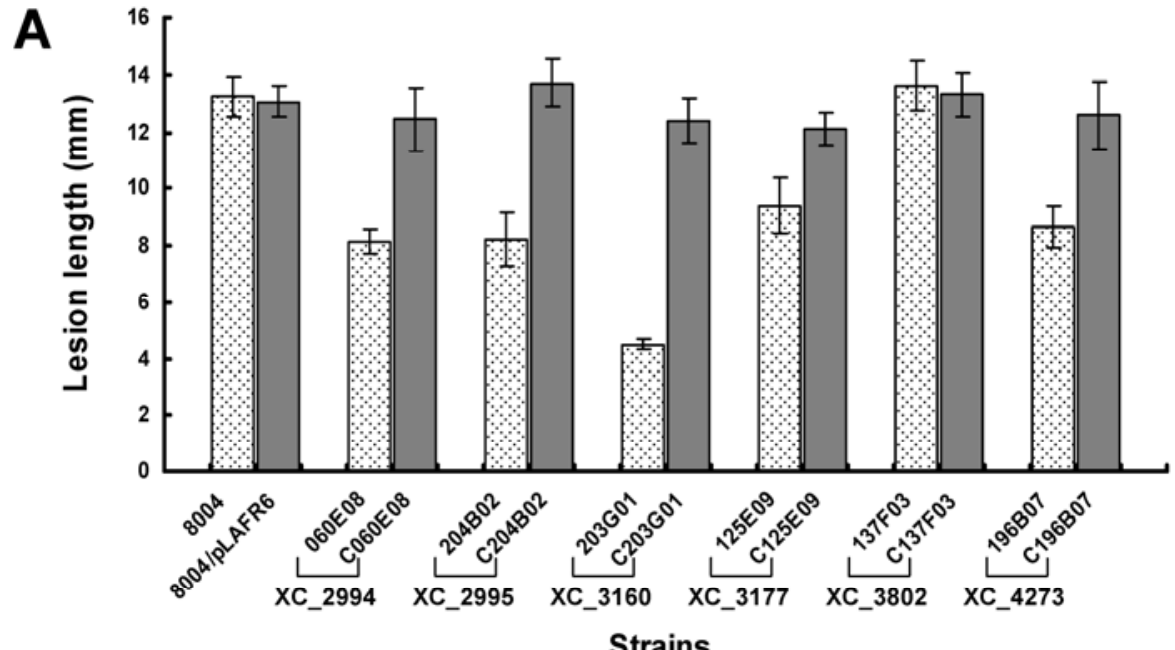

B
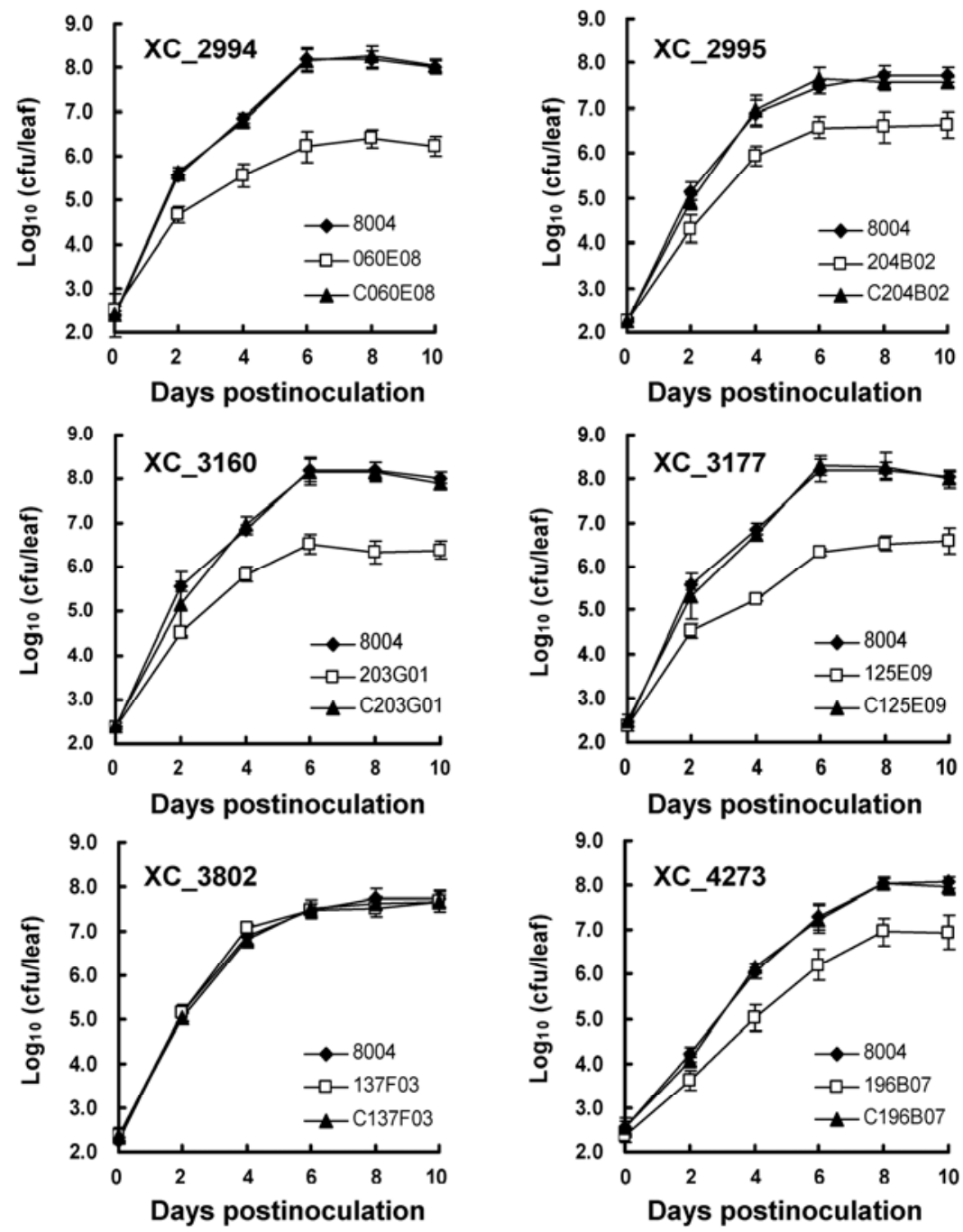

Fig. 2. Type III secreted (T3S) effectors XC_2994, XC_2995, XC_3160, XC_3177, and XC_4273 but not XC_3802 contribute individually to the full pathogenicity of Xanthomonas campestris pv. campestris. A, Virulence of $X$. campestris pv. campestris strains. The average lesion lengths caused by the mutants $(060 \mathrm{E} 08,204 \mathrm{~B} 02,203 \mathrm{G} 01,125 \mathrm{E} 09$, and 196B07) of the T3S-effector genes XC_2994, XC_2995, XC_3160, XC_3177, and XC_4273 are significantly shorter than that caused by the wild-type $8004(P=0.01$ by $t$ test). The average lesion lengths caused by the mutant (137F03) of the T3Seffector gene XC_3802, the complemented strains (C060E08, C204B02, C203G01, C125E09, C137F03, and C196B07), the wild type, and the wild type harboring the vector plasmid pLAFR6 (8004/pLAFR6) are similar. Values are the mean \pm standard deviation (SD) from three repeats, each with 60 leaves. The lesion lengths were measured 10 days postinoculation. B, The in planta growth of $X$. campestris pv. campestris strains. The bacterial numbers (CFU) of the mutants $(060 \mathrm{E} 08,204 \mathrm{~B} 02,203 \mathrm{G} 01,125 \mathrm{E} 09$, and 196B07) of the T3S-effector genes XC_2994, XC_2995, XC_3160, XC_3177, and XC_4273, recovered from the infected leaves, are significantly fewer $(P=0.01$ by $t$ test) than that of the wild-type strain 80044 days postinoculation and onward. There is no significant difference between the bacterial numbers of the wild type and the complemented strains C060E08, C204B02, C203G01, C125E09, and C196B07. The bacterial numbers of the mutant 137F03 of the effector gene XC_3802, the complemented strain C137F03, and the wild type are almost identical. Data are the mean \pm SD from three repeats. 
rates of the mutant $137 \mathrm{~F} 03$, the wild type, and all of the complemented strains (Fig. 2B). This suggests that the growth capacity of the five virulence-reduced mutants in planta could be restored by in trans complementation. These data reveal that the T3S-effector genes XC_2994, XC_2995, XC_3160, $X C_{-} 3177$, and $X C_{\_} 4273$ are required for $X$. campestris pv. campestris to proliferate well in host plants.

\section{DISCUSSION}

As described above, T3S effectors play important roles in molecular interactions between a phytopathogen and its hosts. The translocation of the effectors into plant cells relies on the effector targeting signal that generally resides in the N-terminal domain (Mudgett et al. 2000; Schechter et al. 2004). In this work, we have identified six T3S effectors of $X$. campestris $\mathrm{pv}$. campestris by employing the HR-inducing domain of the Avr protein AvrBs1 as a reporter to analyze the translocation capability of the N-termini of proteins encoded by the genes with a PIP motif. By gus-reporter analyses, we showed that the expression of all of these effectors is positively regulated by the hrp regulators $\mathrm{HrpX}$ and $\mathrm{HrpG}$, and their translocation into plant cells relies on the translocon protein $\mathrm{HrpF}$ and the chaperone HpaB. Koebnik and associates (2006) have demonstrated by DNA affinity enrichment that the $\operatorname{HrpX}$ of $X$. campestris pv. vesicatoria specifically binds to the PIP boxes present in the promoters of hrp operons, suggesting that HrpX directly activates the expression of HrpX-regulated genes via binding to corresponding PIP boxes. In $X$. oryzae pv. oryzae, the PIP boxes also have been shown to be essential for HrpXdependent gene activation (Furutani et al. 2006). Because the $h r p$ cluster and the $h r p$ key regulators $h r p X$ and $h r p G$ are highly conserved among different Xanthomonas spp. and pathovars, it has been considered that the regulation of the hrp genes may be similar among different Xanthomonas bacteria. It is possible that the expression of the T3S-effector-coding genes with the PIP box identified in this work is directly initiated by HrpX. However, an alternative regulatory model has been proposed by Koebnik and associates (2006). They suggested that HrpX may activate genes independent of a PIP box, one of which encodes a regulator which recognizes the PIP box and activates the corresponding genes. Therefore, in $X$. campestris pv. campestris, whether HrpX directly activates the expression of the T3S effectors needs to be validated by further experimental evidence.

In addition to strain 8004, the genome sequences of two other strains (ATCC 33913 and B100) of X. campestris pv. campestris have been also determined (da Silva et al. 2002; Vorhölter et al. 2008). A database sequence comparison displayed that all of the effectors identified in this work from strain 8004, with the exception of XC_3802, are present in strains ATCC 33913 and B100, and the homologs for each of them are almost identical (Table 2). XC_3802 is present in strain ATCC 33913 but not B100 (Table 2). This observation fits with the results of our previous array-based comparative genome hybridization (aCGH) analyses of 18 virulent $X$. campestris pv. campestris strains, isolated from different host plants and various geographical regions over a wide range of latitudes across China, which showed that the ORF XC_3802 homologs are only present in 8 of the strains, whereas orthologs of the other five effector-coding ORF (i.e., $X C \_2994, X C_{\_} 2995, X C_{\_} 3160, X C_{\_} 3177$ and XC_4273) are present in all of the 18 strains (He et al. 2007). These may suggest that the effectors, except XC_3802, are highly conserved among $X$. campestris pv. campestris strains. These facts may also imply that, in $X$. campestris pv. campestris, the T3S effectors contributing significantly to pathogenicity, no matter whether they were acquired or inherent, may be eternal; otherwise, they will be lost during evolution.

A further protein BLAST analysis revealed that homologs or analogs of XC_2994, XC_3177, and XC_4273 are present in all sequenced Xanthomonas spp. (i.e., X. campestris pv. vesicatoria, $X$. oryzae pv. oryzae, $X$. oryzae pv. oryzicola, and $X$. axonopodis pv. citri) whereas XC_2995 homologs or analogs are present only in $X$. campestris pv. vesicatoria and $X$. axonopodis pv. citri, and the XC_3802 homolog or analog is present only in $X$. campestris pv. vesicatoria (Table 2). In addition, homologs or analogs of all the effectors are also present in Ralstonia solanacearum and three of them are present in P. syringae pv. tomato (Table 2).

Table 2. Distribution of the six type III secreted (T3S) effectors among other phytopathogenic bacteria ${ }^{\mathrm{u}}$

\begin{tabular}{|c|c|c|c|c|c|c|c|c|c|c|}
\hline \multicolumn{3}{|c|}{ Xanthomonas campestris pv. campestris } & \multirow[b]{2}{*}{$85-10^{v}$} & \multicolumn{3}{|c|}{ X. oryzae pv. oryzae } & \multirow[b]{2}{*}{ BLS256 $^{\mathrm{w}}$} & \multirow[b]{2}{*}{$306^{x}$} & \multirow[b]{2}{*}{ GMI1000 $^{y}$} & \multirow[b]{2}{*}{$\mathrm{DC3000}^{\mathrm{z}}$} \\
\hline 8004 & ATCC33913 & B100 & & KACC10331 & PXO99A & MAFF311018 & & & & \\
\hline ХорХссР & XCC1247 & xccb100_305 & ХорР & & & & & & hlk3 & \\
\hline XC_2994 & $(99 / 100)$ & $7(99 / 99)$ & $\begin{array}{l}\text { XCV1236 } \\
(38 / 56)\end{array}$ & $\begin{array}{l}\text { XOO3425 } \\
(39 / 58)\end{array}$ & $\begin{array}{l}\text { PXO_021 } \\
07(39 / 57)\end{array}$ & $\begin{array}{l}\text { XOO_3222 } \\
(39 / 57)\end{array}$ & $\begin{array}{l}\text { Xoryp_06110 } \\
(42 / 61)\end{array}$ & $\begin{array}{l}\text { XAC120 } \\
8(39 / 56)\end{array}$ & $\begin{array}{l}\text { RSp0160 } \\
(35 / 54)\end{array}$ & $\mathrm{N}$ \\
\hline XopXccE1 & XCC1246 & xccb100_305 & XopE1 & & & & & & AvrPphE & HopX1 \\
\hline XC_2995 & $(100 / 100)$ & $8(100 / 100)$ & $\begin{array}{l}\text { XCV0294 } \\
(26 / 40)\end{array}$ & $\mathrm{N}$ & $\mathrm{N}$ & $\mathrm{N}$ & $\mathrm{N}$ & $\begin{array}{l}\text { XAC028 } \\
6(24 / 38)\end{array}$ & $\begin{array}{l}\text { RSc3369 } \\
(27 / 45)\end{array}$ & $\begin{array}{l}\text { PSPTOA0 } \\
012 \\
(25 / 40)\end{array}$ \\
\hline $\begin{array}{l}\text { XopXccR1 } \\
\text { XC_3160 }\end{array}$ & $\begin{array}{l}\text { XCC1089 } \\
(100 / 100)\end{array}$ & $\begin{array}{l}\text { xccb100_325 } \\
6(99 / 100)\end{array}$ & $\mathrm{N}$ & $\mathrm{N}$ & $\mathrm{N}$ & $\mathrm{N}$ & $\mathrm{N}$ & $\mathrm{N}$ & $\begin{array}{l}\text { RSp1281 } \\
(26 / 39)\end{array}$ & $\begin{array}{l}\text { HopR1 } \\
\text { PSPTO08 } \\
83(49 / 64)\end{array}$ \\
\hline $\begin{array}{l}\text { XopXccQ } \\
\text { XC_3177 }\end{array}$ & $\begin{array}{l}\text { XCC1072 } \\
(99 / 99)\end{array}$ & $\begin{array}{l}\text { XopQ } \\
\text { xccb100_327 } \\
4(99 / 100)\end{array}$ & $\begin{array}{l}\text { XopQ } \\
\text { XCV4438 } \\
(63 / 74)\end{array}$ & $\begin{array}{l}\text { XOO4466 } \\
(64 / 75)\end{array}$ & $\begin{array}{l}\text { PXO_039 } \\
01(64 / 75)\end{array}$ & $\begin{array}{l}\text { XOO4208 } \\
(61 / 72)\end{array}$ & $\begin{array}{l}\text { Xoryp_00510 } \\
(63 / 74)\end{array}$ & $\begin{array}{l}\text { XAC433 } \\
3(63 / 74)\end{array}$ & $\begin{array}{l}\mathrm{RSc} 0245 \\
(47 / 62)\end{array}$ & $\begin{array}{l}\text { HopQ1-1 } \\
\text { PSPTO08 } \\
77(61 / 72)\end{array}$ \\
\hline $\begin{array}{l}\text { AvrXccB } \\
\text { XC_3802 }\end{array}$ & $\begin{array}{l}\text { XCC3731 } \\
(99 / 100)\end{array}$ & (1) & $\begin{array}{l}\text { XopJ } \\
\text { XCV2156 } \\
(24 / 41)\end{array}$ & (2) & (1) & $(017,1)$ & (1) & ) & $\begin{array}{l}\text { PopP2 } \\
\text { RSc0321 } \\
(24 / 37)\end{array}$ & (1) \\
\hline $\begin{array}{l}\text { XopXccLR } \\
\text { XC_4273 }\end{array}$ & $\begin{array}{l}\text { XCC4186 } \\
(100 / 100)\end{array}$ & $\begin{array}{l}\text { xccb100_440 } \\
0(99 / 100)\end{array}$ & $\begin{array}{l}\text { XCV3220 } \\
(43 / 60)\end{array}$ & $\begin{array}{l}\text { XOO1762 } \\
(41 / 58)\end{array}$ & $\begin{array}{l}\text { PXO_016 } \\
20(42 / 59)\end{array}$ & $\begin{array}{l}\text { XOO1662 } \\
(41 / 58)\end{array}$ & $\begin{array}{l}\text { ZP_0224412 } \\
7(40 / 58)\end{array}$ & $\begin{array}{l}\text { XAC309 } \\
0(42 / 59)\end{array}$ & $\begin{array}{l}\text { RSp0842 } \\
(29 / 45)\end{array}$ & $\mathrm{N}$ \\
\hline
\end{tabular}

" Numbers in parentheses represent percentages of amino-acid identity or similarity; $\mathrm{N}$ denotes no homologous (or similar) gene was found.

${ }^{\mathrm{v}} X$. campestris pv. vesicatoria.

${ }^{\mathrm{w}} X$. oryzae pv. oryzicola.

${ }^{\mathrm{x}} X$. axonopodis pv. citri.

${ }^{\mathrm{y}}$ Ralstonia solanacearum.

${ }^{\mathrm{z}}$ Pseudomonas syringae pv. tomato. 
The ORF coding for the effectors XC_2994 and XC_2995 lie side by side on the chromosomes of all sequenced $X$. campestris pv. campestris strains, whereas the loci of their homologs or analogs are disconnected in $X$. campestris pv. vesicatoria, $X$. axonopodis pv. citri, and $R$. solanacearum. Interestingly, the three ORF next to the left and right flanks of XC_2994 and $X C \_2995$ encode putative mobile elements; that is, a putative IS1479 transposase (XC_2993) and two putative IS1404 transposases (XC_2996 and XC_2997) (Fig. 3) (Qian et al. 2005). Furthermore, the GC contents of XC_2994 and XC_2995 are 57 and $49 \%$, respectively, which are much lower than the $65 \%$, in average, of the $X$. campestris pv. campestris genome. These suggest that the effectors XC_2994 and XC_2995 of X. campestris pv. campestris are horizontally acquired. More interestingly, the predicted ORF XC_2992, XC_2999, and XC_3000 of X. campestris pv. campestris share more than $70 \%$ DNA sequence identity with the $5^{\prime}$ terminal, middle, and $3^{\prime}$ terminal sequences of the ORF XCV0442 of X. campestris pv. vesicatoria, respectively (Fig. 3), hinting that the allele of XCV0442 in X. campestris pv. campestris was truncated in the ancient bacterium. An analysis of the determined genome sequences showed that XCV0442 and its alleles in other Xanthomonas spp. share high sequence identity and are tightly flanked by the hrp gene cluster (Fig. 3). The hrp cluster is conserved in Xanthomonas spp. and is a typical pathogenicity island acquired by horizontal gene transfer (Dobrindt et al. 2004; Gürlebeck et al. 2006). XC_2998 and its alleles in the other two $X$. campestris pv. campestris strains are identical and have been annotated to encode a hypothetical protein. Our previous aCGH analyses revealed that, like XC_2994 and XC_2995, XC_2998 is highly conserved in all 18 different $X$. campestris pv. campestris strains tested (He et al. 2007). However, no homolog or analog of XC_2998 is present in other sequenced Xanthomonas spp. Taken together, all of these facts may indicate that the effectors XC_2994 and XC_2995 were horizontally acquired after the acquisition of the hrp cluster in X. campestris pv. campestris.

The effector XC_2994 shows 39\% (58\%) amino-acid identity (similarity) to the effector XopP, which was identified from $X$. campestris pv. vesicatoria (Table 2), and its function is unknown (Roden et al. 2004). A BLAST search against the $X$. campestris pv. campestris 8004 genome with the effector XopP of $X$. campestris pv. vesicatoria revealed no other sequence-similar deduced protein except XC_2994. Therefore, we renamed XC_2994 as XopXccP. The effector XC_2995 shares $26 \%(40 \%)$ amino-acid identity (similarity) with the $X$. campestris pv. vesicatoria effector XopE1 (Table 2). XopE1 belongs to the HopX (AvrPphE) family of putative transglutaminases, with a cysteine-based catalytic triad essential for function (Nimchuk et al. 2007; Thieme et al. 2007). An alignment analysis showed that XC_2995 possesses a catalytic triad (122 cysteine, 152 histidine, and 174 aspartic acid) and a conserved N-terminal domain (data not shown), suggesting that XC_2995 may belong to the HopX (AvrPphE) family. Therefore, we renamed XC_2995 as XopXccE1.

The effector XC_3160 shares 49\% (64\%) amino-acid identity (similarity) with the effector HopR 1 identified from $P$. syringae (Chang et al. 2005; Schechter et al. 2006), although it exists only in $X$. campestris pv. campestris among the sequenced Xanthomonas spp. and pathovars (Table 2). Based on the aminoacid sequence similarity, we renamed XC_3160 as XopXccR1. The function of HopR 1 in the interaction between the pathogen and hosts is unknown because no mutant phenotype in planta for HopR1 has been observed (Chang et al. 2005; Schechter et al. 2006). Similar to HopR1, the predicted XopXccR1, consisting of 2,032 amino acids, is one of the few very large proteins deduced in X. campestris pv. campestris (Qian et al. 2005). To predict the secondary structure of XopXccR1, we performed a three-dimensional position-specific scoring matrix (3D-PSSM)

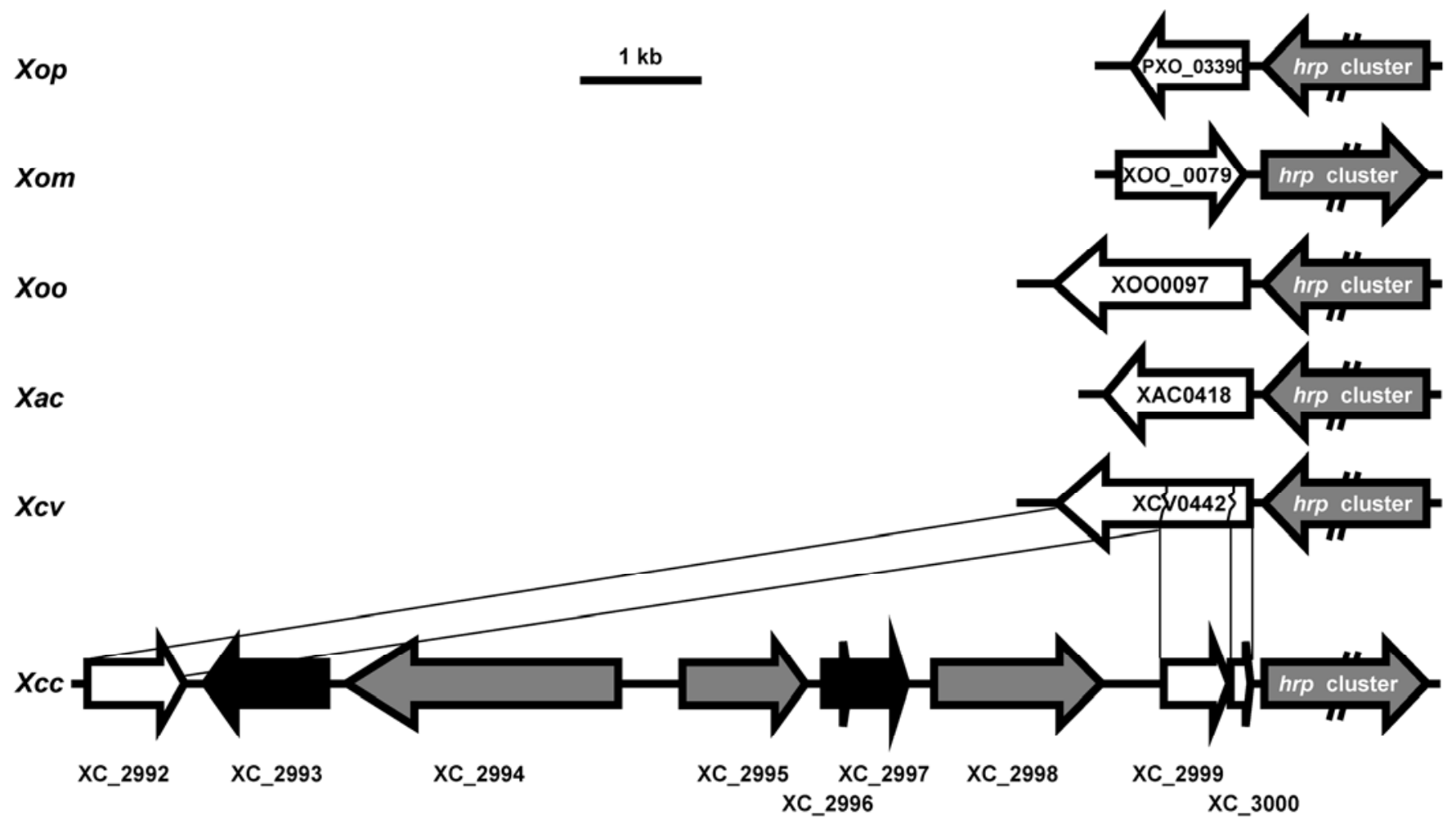

Fig. 3. XC_2994 and XC_2995 were horizontally acquired after the acquisition of the hypersensitive response and pathogenicity ( $h r p$ ) cluster in Xanthomonas campestris pv. campestris. The open reading frames (ORF) XC_2992, XC_2999, and XC_3000 of the X. campestris pv. campestris 8004 are homologous to the 5' terminal, middle, and 3' terminal sequences, respectively, of the ORF XCV0442 of X. campestris pv. vesicatoria. The ORF XC_2993, XC_2996, and $X C \_2997$ encode putative transposases. 
analysis (www.sbg.bio.ic.ac.uk/ 3dpssm) (Kelley et al. 2000). Interestingly, the result showed that the N-terminal domain of XopXccR1 shares structural homology with the extracellular domain of mycobacterium tuberculosis serine/threonine protein kinase $\mathrm{PknD}$, while the middle region shares structural homology with a superfamily of proteins containing tandemly repeated $\alpha$-helices, known as ARM/HEAT repeats, which are commonly present in eukaryotes but are rare in bacteria (Andrade et al. 2001; Roden et al. 2004), and the C-terminal region is homologous to the constant regulatory domain of the protein phosphatase $2 \mathrm{~A}$. Protein phosphatase $2 \mathrm{~A}$ is a highly regulated family of eukaryotic serine/threonine phosphatases implicated in cell growth and signaling (Janssens and Goris 2001). As a T3SS-effector protein, XopXccR1, with such eukaryotic structural motifs, may be significant for the pathogen to manipulate its host plants.

XC_3177 shows more than $60 \%$ amino-acid sequence identity to the $X$. campestris pv. vesicatoria effector XopQ (Roden et al. 2004) and the P. syringae pv. tomato effector HopQ1-1 (Wei et al. 2007a) (Table 2). Based on the sequence similarity, we renamed XC_3177 as XopXccQ. Although the $x o p Q$ mutant of $X$. campestris pv. vesicatoria exhibited no significant growth defect in susceptible host plants pepper and tomato (Roden et al. 2004), HopQ1-1 of P. syringae pv. tomato has been demonstrated to be an Avr protein (Wei et al. 2007a). BLAST analysis showed that XopXccQ contains a nuc_hydro_2 (NH_2) domain, a subgroup of nucleoside hydrolases, with an $E$ value of $1 \mathrm{e}^{-60}$. These nucleoside hydrolases have been found in eukaryotes and prokaryotes. They cleave the N-glycosidic bond in nucleosides generating ribose and the respective base and vary in their substrate specificity.

XC_3802 shares 24\% (41\%) amino-acid identity (similarity) with the effector XopJ of X. campestris pv. vesicatoria (Noël et al. 2003). XopJ probably belongs to the YopJ/AvrRxv family of C55 cysteine proteases (Kay and Bonas 2009). Analysis of the predicted amino-acid sequence of XC_3802 showed that XC_3802 possesses the conserved characteristics of cysteine proteases (data not shown), suggesting that the effector XC_3802 may also be a member of the YopJ/AvrRxv family. As mentioned above, XC_3802 was annotated as the Avr protein AvrXccB; therefore, we retained XC_3802 as AvrXccB although its authentic avirulence function remains to be further evaluated. XC_3802 is almost identical to the XCC3731 of the $X$. campestris pv. campestris ATCC33913 $\left(528^{\mathrm{T}}\right)$ (Table 2). Although whether XCC3731 in strain ATCC33913 (528 $)$ is a T3S effector has not been experimentally validated, it has been demonstrated that mutation of XCC3731 did not affect the pathogenicity of strain ATCC33913 $\left(528^{\mathrm{T}}\right)$ on a number of host species (Castañeda et al. 2005). This study also showed that mutation of $X C_{-} 3802$ did not affect the virulence and growth of strain 8004 either. As described above, $X C_{-} 3802$ is expendable among virulent strains. Being secreted into host cells, whether the effector AvrXccB plays any role in the interaction between $X$. campestris pv. campestris and plants needs further investigations.

$X C_{-} 4273$ and $X C_{-} 1553$ in $X$. campestris pv. campestris 8004 were predicted to encode proteins containing the leucinerich repeat (LRR) motif (Qian et al. 2005). The LRR motif is a typical protein motif commonly observed in eukaryotic proteins and appears to be implicated in the mediation of proteinprotein interactions (Kobe and Kajava 2001). LRR-containing proteins have been shown to be involved in the host defense systems of both plants and mammals, and many plant $R$ genes identified to date encode proteins possessing the LRR motif (Kobe and Kajava 2001; Jones and Dangl 2006). LRR motifcontaining proteins have also been found in diverse groups of animal and plant bacterial pathogens and some of them have been shown to be T3S effectors; for instance, PopC and GALAs from $R$. solanacearum (Gueneron et al. 2000; Angot et al. 2006). Recently, we have demonstrated that XC_1553 of $X$. campestris pv. campestris, which was renamed as $\mathrm{AvrAC}_{\mathrm{Xcc8004}}$, is a T3S effector and functions as an Avr protein, which seems to be recognized in vascular tissues of $A$. thaliana ecotype Col-0 (Xu et al. 2008). Although homologs or analogs of XC_4273 are present in a number of other pathogens (Table 2), whether they are T3S effectors is unknown. We renamed the effector XC_4273 as XopXccLR (LR = leucine-rich repeat).

We would like to point out that the technique using AvrBs1 as a reporter and pepper for the translocation assay to identify T3S effectors in this study may have limitations, because pepper is not the host of $X$. campestris pv. campestris and AvrBs1 may have a high threshold level for HR induction. The effectors secreted in a relatively low amount might not be identified by this method. Therefore, in addition to the above six genes, whether any of the other genes with the PIP box listed in Supplementary Table S1 encode T3S effectors needs further investigations by other methods such as the cya assay (Casper-Lindley et al. 2002). Furthermore, a number of T3S effectors identified from different Xanthomonas pathogens are encoded by genes without a PIP box. It is not doubted that $X$. campestris pv. campestris may also possess T3S-effector genes without a PIP box. The deduced proteins encoded by the non-PIP-box-containing genes $X C_{-} 0052, X C_{-} 0241$, and $X C_{-} 2210$ in the $X$. campestris pv. campestris 8004 share more than $80 \%$ amino-acid identity with the $\mathrm{T} 3 \mathrm{~S}$ effectors identified from $X$. oryzae pv. oryzae (Furutani et al. 2009), implying that they may be T3S effectors. Further identification of the T3S effectors encoded by non-PIPbox-containing genes in $X$. campestris pv. campestris has been recently initiated in our laboratory.

Many studies have shown that a block in the T3SS of a pathogenic bacterium results in a severe reduction in virulence and in planta growth of the pathogen, indicating that the T3S effectors in a pathogen contribute collectively to pathogenicity. However, apart from $a v r$ genes, for the overwhelming majority of T3Seffector genes identified from different pathogens so far, mutations affecting individual genes in a given pathogen gave no significant phenotypes. This may be due to apparent redundancy of the effectors in a pathogen (Gürlebeck et al. 2006; Schechter et al. 2006; Wei et al. 2007a). Interestingly, among the six T3S effectors of $X$. campestris pv. campestris identified in this work, five showed individually a significant contribution to the full virulence and growth of the pathogen in host plants. Does this mean that $X$. campestris pv. campestris harbors fewer T3S effectors with functional redundancy than other pathogens? How do these effectors contribute to disease development? These will be topics that merit further investigations.

\section{MATERIALS AND METHODS}

\section{Bacterial strains, plasmids, and growth conditions.}

The bacterial strains and plasmids used in this work are listed in Supplementary Table S2. All of the X. campestris pv. campestris strains were grown at $28^{\circ} \mathrm{C}$ in the rich medium $\mathrm{NYG}$ (Daniels et al. 1984) or the minimal medium MMX (Daniels et al. 1984). Escherichia coli strains were grown in LB medium (Miller 1972) at $37^{\circ} \mathrm{C}$. Antibiotics were used at the following final concentrations as required: gentamycin $(\mathrm{Gm}), 5 \mu \mathrm{g} / \mathrm{ml}$; kanamycin $(\mathrm{Km}), 25 \mu \mathrm{g} / \mathrm{ml}$; rifampicin (Rif), $50 \mu \mathrm{g} / \mathrm{ml}$; spectinomycin (Spc), $50 \mu \mathrm{g} / \mathrm{ml}$; and tetracycline (Tc), $15 \mu \mathrm{g} / \mathrm{ml}$ for $E$. coli and $5 \mu \mathrm{g} / \mathrm{ml}$ for $X$. campestris pv. campestris.

\section{DNA manipulations.}

Standard DNA manipulations were performed following the procedures described by Sambrook and associates (1989). The 
conjugation between the $X$. campestris pv. campestris and $E$. coli strains was performed as described by Turner and associates (1985). Restriction enzymes and DNA ligase were used in accordance with the manufacturer's instructions (Promega, Shanghai, China).

\section{Mutant construction and complementation.}

The Tn5gusA5 insertional mutants of the six identified T3Seffector-coding genes $\left(X C \_2994, \quad X C \_2995, \quad X C \_3160\right.$, $X C_{\_} 3177, X C_{-} 3802$, and $\left.X C_{-} 4273\right)$, named 060E08, 204B02, 203G01, 125E09, 137F03, and 196B07, were from the insertional mutant library of the $X$. campestris pv. campestris 8004 in the authors' laboratory. The mutants were selected by mating the $X$. campestris pv. campestris $8004 /$ pLAFR $1:: T n 5$ gusA5 with 8005/pPH1JI (Turner et al. 1985) (the plasmids pPH1JI [Gm- and Spc-resistant] [Hirsch and Beringer 1984] and pLAFR1 [Tc-resistant] are incompatible) and by plating them on the NYG selection medium containing Rif (for 8004), Km (for Tn5gusA5), Gm, and Spc (for pPH1JI). The Rif-Km-GmSpc-resistant but Tc-sensitive individual transconjugants were chosen as candidate mutants. The genomic positions of the transposon Tn5gusA5 in the mutants were determined by thermal asymmetric interlaced polymerase chain reaction (PCR) (Liu and Huang 1998) and subsequent sequencing for comparison with the whole genome sequence of strain 8004 (Qian et al. 2005). The insertional site of Tn5gusA5 was further confirmed by PCR using the primers on transposon and on the gene upstream or downstream of the gene disrupted.

For complementation of the mutants, the DNA fragments containing the entire individual effector genes were amplified by PCR using the total DNA of the $X$. campestris pv. campestris 8004 as the template and the primer sets listed in Supplementary Table S3. After confirmation by sequencing, the amplified DNA fragments were cloned into pLAFR6. The obtained recombinant plasmids and the control plasmid pLAFR6 were transferred into the corresponding Tn5gusA5 insertion mutants by triparental conjugation. The transconjugants were screened on NYG plates with appropriate antibiotics.

An hpaB mutant was constructed by homologous suicide plasmid integration as described by Windgassen and associates (2000). A 356-bp internal fragment of the $h p a B$ gene (XC_3022, AAY50070) was amplified using the total DNA of the $\bar{X}$. campestris. pv. campestris 8004 as template and the primer set $\mathrm{XC} 3022 \mathrm{~F} / \mathrm{XC} 3022 \mathrm{R}$. After confirmation by sequencing, the amplified DNA fragment was cloned into pK18mob (Schafer et al. 1994) to create the recombinant plasmid pK3022. The pK3022 was introduced from E. coli JM109 (Yanisch-Perron et al. 1985) into the $X$. campestris. pv. campestris 8004 by triparental conjugation. Transconjugants were screened on NYG plates supplemented with Rif and $\mathrm{Km}$, and the obtained transconjugants with a mutation in the $h p a B$ gene were confirmed by PCR. Confirmation PCR was performed using the total DNA of the obtained transconjugants as templates and the primers P18conF (located in pK18mob) and XC3023R (located downstream of the $h p a B$ gene). The expected PCR products were further confirmed by sequencing. A negative control was performed using the same primers and the total DNA of the $X$. campestris. pv. campestris 8004 as the template. One of the confirmed transconjugants was randomly selected for further study and named $8004 \Delta \mathrm{hpaB}$. For complementation of $8004 \Delta \mathrm{hpaB}$, the 1,461-bp fragment containing 483-bp hpaB ORF and its 542-bp upstream and 436-bp downstream flanking sequences was amplified by PCR using the total DNA of the $X$. campestris pv. campestris 8004 as the template and the primer set C3022-F/C3022-R, and cloned into pLAFR6 to generate the plasmid $\mathrm{pLhpaB}$. The plasmid $\mathrm{pLhpaB}$ was introduced into the mutant $8004 \Delta \mathrm{hpaB}$ by triparental con- jugation, generating the complemented strain 8004 $\Delta \mathrm{hpaB} /$ pLhpaB. The $h r p F$-deletion mutant strain $8004 \Delta \mathrm{hrpF}$ was constructed previously (Jiang et al. 2008).

\section{Translocation assay.}

To facilitate the identification of T3S effectors of $X$. campestris pv. campestris, the reporter plasmid pJAG was constructed. The artificial synthesized fragment of $3 \times$ FLAG was cloned into the PstI and HindIII sites of pLAFRJ, a derivate of pLAFR3, which contains the multiple cloning sites of pUC19, generating the plasmid pJXG. The 1,174-bp DNA fragment of the $3^{\prime}$ end of $a v r B s 1$ was amplified using the total DNA of the $X$. campestris pv. campestris 8004 as the template and the primer set 59aa-F/445aa-R (Xu et al. 2008). After confirmation by sequencing, the fragment was cloned into the $\mathrm{Xba \textrm {I }}$ and $P s t \mathrm{I}$ sites of pJXG, yielding the recombinant plasmid pJAG. The validities of $\mathrm{pJAG}$ in secretion and translocation assay were confirmed with the known T3S effector XopXccN (data not shown). The DNA fragments containing the putative promoter and T3S signal sequence of candidate genes were amplified using the total DNA of $X$. campestris pv. campestris 8004 as the template and the primer sets. After confirmation by sequencing, the fragments were cloned into $\mathrm{pJAG}$ to generate a series of recombinant plasmids. The obtained recombinant plasmids were introduced into the $a v r B s l$-deletion mutant (8004 $\Delta$ avrBs1), $h r p F$-deletion mutant $(8004 \Delta \mathrm{hrpF})$, and $h p a B$ integration mutant $(8004 \Delta \mathrm{hpaB})$ by triparental conjugation.

The ability of the obtained strains to elicit HR was tested on pepper ECW-10R (Capsicum annuum cv. ECW-10R), a nonhost plant commonly used to test the HR of $X$. campestris pv. campestris (Castañeda et al. 2005; Xu et al. 2008). Bacterial cells suspended in $10 \mathrm{mM}$ sodium phosphate buffer $(5.8 \mathrm{mM}$ $\mathrm{Na}_{2} \mathrm{HPO}_{4}$ and $\left.4.2 \mathrm{mM} \mathrm{NaH} \mathrm{PO}_{4}, \mathrm{pH} 7.0\right)$ at an optical density $600\left(\mathrm{OD}_{600}\right)$ of 0.3 were hand infiltrated into the leaf tissues using a needleless syringe. The inoculated plants were maintained in a greenhouse with a day and night cycle of 16 and 8 $\mathrm{h}$, respectively, with illumination by fluorescent lamps and a constant temperature of $28^{\circ} \mathrm{C}$ at $80 \%$ relative humidity. At least three plants were inoculated in each experiment and each experiment was repeated at least three times. HR symptoms were photographed $24 \mathrm{~h}$ postinoculation in the $8004 \Delta$ avrBs 1 background or $72 \mathrm{~h}$ postinoculation in the $8004 \Delta \mathrm{hrpF}$ or $8004 \Delta$ hpaB background.

\section{Transcription assay.}

The reporter plasmid pLGUS, harboring the promoterless gusA gene in the BamHI/SphI sites of pLAFR6 (Jiang et al. 2008), was employed to determine the transcription level of the identified T3S-effector genes. The DNA fragments containing the putative promoters of the identified T3S-effector genes were cloned into pLGUS. The attained recombinant plasmids were introduced into the wild-type 8004, the hrpGdeletion mutant $8004 \Delta \mathrm{hrpG}$, and the hrpX-deletion mutant $8004 \Delta \mathrm{hrpX}$ by triparental conjugation. The transconjugants were screened on NYG plates with appropriate antibiotics and assayed for GUS activity. The transconjugant strains were grown in NYG for $16 \mathrm{~h}$ or MMX for $24 \mathrm{~h}$ and their GUS activities were detected by measurement of the $\mathrm{OD}_{415}$ using $\rho$ nitrophenyl- $\beta$-D-glucuronide as substrate, as described by Jefferson and associates (1986).

\section{Virulence assay and determination of bacterial load in planta.}

The virulence of $X$. campestris pv. campestris strains was tested on potted Chinese radish (Raphanus sativus var. radiculus) cv. Manshenhong grown in a greenhouse with a day and night cycle of 12 and $12 \mathrm{~h}$, respectively, with illumination by 
fluorescent lamp at temperatures of 25 to $28^{\circ} \mathrm{C}$ as described previously (Tang et al. 2005). Seedlings with four fully expanded leaves were used for inoculation. Bacterial cells were grown in NYG medium at $28^{\circ} \mathrm{C}$ with shaking at $200 \mathrm{rpm}$ for $15 \mathrm{~h}$. The cell concentration was adjusted to $\mathrm{OD}_{600}=0.001$. Two leaves per plant were inoculated by the leaf-clipping method (Dow et al. 2003). Sixty leaves were inoculated for each strain in each independent experiment. After being maintained at $100 \%$ humidity for $24 \mathrm{~h}$, the inoculated plants were maintained in the growth conditions described above. Lesion length was measured 10 days postinoculation. Experiments were repeated independently three times.

To determine the bacterial growth of $X$. campestris pv. campestris strains in planta, Chinese radish leaves were inoculated by the same method used for the virulence test as described above, and five inoculated leaves for each sampling were homogenized in $9 \mathrm{ml}$ of sterile water. Diluted homogenates were plated on NYG plates supplemented with appropriate antibiotics. Bacterial CFU were counted after incubation at $28^{\circ} \mathrm{C}$ for 3 days.

\section{ACKNOWLEDGMENTS}

This work was supported by the '973' Program of the Ministry of Science and Technology of China (2006CB101902) and the National Science Foundation of China (30870071 and 30770075).

\section{LITERATURE CITED}

Alfano, J. R., and Collmer, A. 2004. Type III secretion system effector proteins: Double agents in bacterial disease and plant defense. Annu. Rev. Phytopathol. 42:385-414.

Alvarez, A. M. 2000. Black rot of crucifers. Pages 21-52 in: Mechanisms of Resistance to Plant Diseases. A. J. Slusarenko, R. S. S. Fraser, and L. C. van Loon, eds. Kluwer Academic Publishers, Dordrecht, The Netherlands.

Andrade, M. A., Petosa, C., O’Donoghue, S. I., Muller, C. W., and Bork, P. 2001. Comparison of ARM and HEAT protein repeats. J. Mol. Biol. 309:1-18.

Angot, A., Peeters, N., Lechner, E., Vailleau, F., Baud, C., Gentzbittel, L., Sartorel, E., Genschik, P., Boucher, C., and Genin, S. 2006. Ralstonia solanacearum requires F-box-like domain-containing type III effectors to promote disease on several host plants. Proc. Natl. Acad. Sci. U.S.A. 103:14620-14625.

Arlat, M., Gough, C. L., Barber, C. E., Boucher, C., and Daniels, M. J. 1991. Xanthomonas campestris contains a cluster of hrp genes related to the larger hrp cluster of Pseudomonas solanacearum. Mol. Plant-Microbe Interact. 4:593-601.

Bonas, U., Schulte, R., Fenselau, S., Minsavage, G. V., Staskawicz, B. J., and Stall, R. E. 1991. Isolation of a gene cluster from Xanthomonas campestris pv. vesicatoria that determines pathogenicity and the hypersensitive response on pepper and tomato. Mol. Plant-Microbe Interact. 4:81-88.

Büttner, D., and Bonas, U. 2006. Who comes first? How plant pathogenic bacteria orchestrate type III secretion. Curr. Opin. Microbiol. 9:193-200.

Büttner, D., Nennstiel, D., Klüsener, B., and Bonas, U. 2002. Functional analysis of HrpF, a putative type III translocon protein from Xanthomonas campestris pv. vesicatoria. J. Bacteriol. 184:2389-2398.

Büttner, D., Gürlebeck, D., Noël, L. D., and Bonas, U. 2004. HpaB from Xanthomonas campestris pv. vesicatoria acts as an exit control protein in type III-dependent protein secretion. Mol. Microbiol. 54:755-768.

Casper-Lindley, C., Dahlbeck, D., Clark, E. T., and Staskawicz, B. J. 2002. Direct biochemical evidence for type III secretion-dependent translocation of the AvrBs2 effector protein into plant cells. Proc. Natl. Acad. Sci. U.S.A. 99:8336-8341.

Castañeda, A., Reddy, J. D., El-Yacoubi, B., and Gabriel, D. W. 2005. Mutagenesis of all eight avr genes in Xanthomonas campestris pv. campestris had no detected effect on pathogenicity, but one $a v r$ gene affected race specificity. Mol. Plant-Microbe Interact. 18:1306-1317.

Chang, J. H., Urbach, J. M., Law, T. F., Arnold, L. W., Hu, A., Gombar, S., Grant, S. R., Ausubel, F. M., and Dangl, J. L. 2005. A high-throughput, near-saturating screen for type III effector genes from Pseudomonas syringae. Proc. Natl. Acad. Sci. U.S.A. 102:2549-2554.

Cunnac, S., Boucher, C., and Genin, S. 2004a. Characterization of the cisacting regulatory element controlling HrpB-mediated activation of the type III secretion system and effector genes in Ralstonia solanacearum.
J. Bacteriol. 186:2309-2318.

Cunnac, S., Occhialini, A., Barberis, P., Boucher, C., and Genin, S. 2004b. Inventory and functional analysis of the large Hrp regulon in Ralstonia solanacearum: Identification of novel effector proteins translocated to plant host cells through the type III secretion system. Mol. Microbiol. 53:115-128.

Daniels, M. J., Barber, C. E., Turner, P. C., Sawczyc, M. K., Byrde, R. J. W., and Fielding, A. H. 1984. Cloning of genes involved in pathogenicity of Xanthomonas campestris pv. campestris using the broad host range cosmid pLAFR1. EMBO (Eur. Mol. Biol. Organ.) J. 3:3323-3328.

da Silva, A. C., Ferro, J. A., Reinach, F. C., Farah, C. S., Furlan, L. R., Quaggio, R. B., Monteiro-Vitorello, C. B., Sluys, M. A., Almeida, N. F., Alves, L. M., Do Amaral, A. M., Bertolini, M. C., Camargo, L. E., Camarotte, G., Cannavan, F., Cardozo, J., Chambergo, F., Ciapina, L. P., Cicarelli, R. M., Coutinho, L. L., Cursino-Santos, J. R., El-Dorry, H., Faria, J. B., Ferreira, A. J., Ferreira, R. C., Ferro, M. I., Formighieri, E. F., Franco, M. C., Greggio, C. C., Gruber, A., Katsuyama, A. M., Kishi, L. T., Leite, R. P., Lemos, E. G., Lemos, M. V., Locali, E. C., Machado, M. A., Madeira, A. M., Martinez-Rossi, N. M., Martins, E. C., Meidanis, J., Menck, C. F., Miyaki, C. Y., Moon, D. H., Moreira, L. M., Novo, M. T., Okura, V. K., Oliveira, M. C., Oliveira, V. R., Pereira, H. A., Rossi, A., Sena, J. A., Silva, C., De Souza, R. F., Spinola, L. A., Takita, M. A., Tamura, R. E., Teixeira, E. C., Tezza, R. I., Trindade Dos Santos, M., Truffi, D., Tsai, S. M., White, F. F., Setubal, J. C., and Kitajima, J. P. 2002. Comparison of the genomes of two Xanthomonas pathogens with differing host specificities. Nature 417:459-463.

Dobrindt, U., Hochhut, B., Hentschel, U., and Hacker, J. 2004. Genomic islands in pathogenic and environmental microorganisms. Nat. Rev. Microbiol. 2:414-424.

Dow, J. M., Crossman, L., Findlay, K., He, Y. Q., Feng, J. X., and Tang, J. L. 2003. Biofilm dispersal in Xanthomonas campestris is controlled by cell-cell signaling and is required for full virulence to plants. Proc. Natl. Acad. Sci. U.S.A. 100:10995-11000.

Fenselau, S., and Bonas, U. 1995. Sequence and expression analysis of the hrpB pathogenicity operon of Xanthomonas campestris pv. vesicatoria which encodes eight proteins with similarity to components of the Hrp, Ysc, Spa, and Fli secretion systems. Mol. Plant-Microbe Interact. 8:845-854.

Furutani, A., Nakayama, T., Ochiai, H., Kaku, H., Kubo, Y., and Tsuge, S. 2006. Identification of novel HrpXo regulons preceded by two cis-acting elements, a plant-inducible promoter box and a -10 box-like sequence, from the genome database of Xanthomonas oryzae pv. oryzae. FEMS (Fed. Eur. Microbiol. Soc.) Microbiol. Lett. 259:133-141.

Furutani, A., Takaoka, M., Sanada, H., Noguchi, Y., Oku, T., Tsuno, K., Ochiai, H., and Tsuge, S. 2009. Identification of novel type III secretion effectors in Xanthomonas oryzae pv. oryzae. Mol. Plant-Microbe Interact. 22:96-106.

Grant, S. R., Fisher, E. J., Chang, J. H., Mole, B. M., and Dangl, J. L. 2006. Subterfuge and manipulation: Type III effector proteins of phytopathogenic bacteria. Annu. Rev. Microbiol. 60:425-449.

Greenberg, J. T., and Vinatzer, B. A. 2003. Identifying type III effectors of plant pathogens and analyzing their interaction with plant cells. Curr. Opin. Microbiol. 6:20-28.

Gueneron, M., Timmers, A. C., Boucher, C., and Arlat, M. 2000. Two novel proteins, PopB, which has functional nuclear localization signals, and PopC, which has a large leucine-rich repeat domain, are secreted through the hrp-secretion apparatus of Ralstonia solanacearum. Mol. Microbiol. 36:261-277.

Gürlebeck, D., Thieme, F., and Bonas, U. 2006. Type III effector proteins from the plant pathogen Xanthomonas and their role in the interaction with the host plant. J. Plant Physiol. 163:233-255.

Guttman, D. S., and Greenberg, J. T. 2001. Functional analysis of the type III effectors AvrRpt2 and AvrRpm1 of Pseudomonas syringae with the use of a single-copy genomic integration system. Mol. Plant-Microbe Interact. 14:145-155.

Guttman, D. S., Vinatzer, B. A., Sarkar, S. F., Ranall, M. V., Kettler, G., and Greenberg, J. T. 2002. A functional screen for the type III (Hrp) secretome of the plant pathogen Pseudomonas syringae. Science 295:1722-1726.

He, Y. Q., Zhang, L., Jiang, B. L., Zhang, Z. C., Xu, R. Q., Tang, D. J., Qin, J., Jiang, W., Zhang, X., Liao, J., Cao, J. R., Zhang, S. S., Wei, M. L., Liang, X. X., Lu, G. T., Feng, J. X., Chen, B., Cheng, J., and Tang, J. L. 2007. Comparative and functional genomics reveals genetic diversity and determinants of host specificity among reference strains and a large collection of Chinese isolates of the phytopathogen Xanthomonas campestris pv. campestris. Genome Biol. 8:R218.

Hirsch, P. R., and Beringer, J. E. 1984. A physical map of pPH1JI and pJB4JI. Plasmid 12:139-141.

Huang, D, L., Tang, D. J., Liao, Q., Li, X. Q., He, Y. Q., Feng, J. X., Jiang, B. L., Lu, G. T., and Tang, J. L. 2009. The Zur of Xanthomonas cam- 
pestris is involved in hypersensitive response and positively regulates the expression of the hrp cluster via $h r p X$ but not hrpG. Mol. Plant-Microbe Interact. 22:321-329.

Huynh, T. V., Dahlbeck, D., and Staskawicz, B. J. Staskawicz. 1989. Bacterial blight of soybean: Regulation of a pathogen gene determining host cultivar specificity. Science 245:1374-1377.

Ignatov, A. N., Monakhos, G. F., Dzhalilov, F. S., and Pozmogova, G. V. 2002. Avirulence gene from Xanthomonas campestris pv. campestris homologous to the avrBs 2 locus is recognized in race-specific reaction by two different resistance genes in Brassica plant species. Genetika 38:1656-1662.

Janssens, V., and Goris, J. 2001. Protein phosphatase 2A: A highly regulated family of serine/threonine phosphatases implicated in cell growth and signalling. Biochem. J. 353:417-439.

Jefferson, R. A., Burges, S. M., and Hirsh, D. 1986. $\beta$-glucuronidase from Escherichia coli as a gene-fusion marker. Proc. Natl. Acad. Sci. U.S.A. 83:8447-8451.

Jiang, B. L., He, Y. Q., Cen, W. J., Wei, H. Y., Jiang, G. F., Jiang, W., Hang, X. H., Feng, J. X., Lu, G. T., Tang, D. J., and Tang, J. L. 2008. The type III secretion effector $\mathrm{XopXccN}$ of Xanthomonas campestris pv. campestris is required for full virulence. Res. Microbiol. 159:216-220.

Jones, J. D., and Dangl, J. L. 2006. The plant immune system. Nature 444:323-329.

Kay, S., and Bonas, U. 2009. How Xanthomonas type III effectors manipulate the host plant. Curr. Opin. Microbiol. 12:37-43.

Kelley, L. A., MacCallum, R. M., and Sternberg, M. J. E. 2000. Enhanced genome annotation using structural profiles in the program 3D-PSSM. J. Mol. Biol. 299:499-520.

Kobe, B., and Kajava, A. V. 2001. The leucine-rich repeat as a protein recognition motif. Curr. Opin. Struct. Biol. 11:725-732.

Koebnik, R., Kruger, A., Thieme, F., Urban, A., and Bonas, U. 2006. Specific binding of the Xanthomonas campestris pv. vesicatoria AraC-type transcriptional activator $\mathrm{HrpX}$ to plant-inducible promoter boxes. J. Bacteriol. 188:7652-7660.

Liu, Y. G., and Huang, N. 1998. Efficient amplification of insert end sequences from bacterial artificial chromosome clones by thermal asymmetric interlaced PCR. Plant Mol. Biol. Rep. 16:175-181.

Meyer, D., Cunnac, S., Gueneron, M., Declercq, C., Van Gijsegem, F., Lauber, E., Boucher, C., and Arlat, M. 2006. PopF1 and PopF2, two proteins secreted by the type III protein secretion system of Ralstonia solanacearum, are translocators belonging to the HrpF/NopX family. J. Bacteriol. 188:4903-4917.

Miller, J. H. 1972. Experiments in Molecular Genetics. Cold Spring Harbor Laboratory Press, Cold Spring Harbor, NY, U.S.A

Mudgett, M. B. 2005. New insights to the function of phytopathogenic bacterial type III effectors in plants. Annu. Rev. Plant Biol. 56:509-531.

Mudgett, M. B., Chesnokova, O., Dahlbeck, D., Clark, E. T., Rossier, O., Bonas, U., and Staskawicz. B. J. 2000. Molecular signals required for type III secretion and translocation of the Xanthomonas campestris AvrBs2 protein to pepper plants. Proc. Natl. Acad. Sci. U.S.A. 97:13324-13329.

Nimchuk, Z. L., Fisher, E. J., Desveaux, D., Chang, J. H., and Dangl, J. L. 2007. The HopX (AvrPphE) family of Pseudomonas syringae type III effectors require a catalytic triad and a novel $\mathrm{N}$-terminal domain for function. Mol. Plant-Microbe Interact. 20:346-357.

Noël, L., Thieme, F., Gäbler, J., Büttner, D., and Bonas, U. 2003. XopC and XopJ, two novel type III effector proteins from Xanthomonas campestris pv. vesicatoria. J. Bacteriol. 185:7092-7102.

Petnicki-Ocwieja, T., Schneider, D. J., Tam, V. C., Chancey, S. T., Shan, L., Jamir, Y., Schechter, L. M., Buell, C. R., Tang, X., Collmer, A., and Alfano, J. R. 2002. Genomewide identification of proteins secreted by the Hrp type III protein secretion system of Pseudomonas syringae pv. tomato DC3000. Proc. Natl. Acad. Sci. U.S.A. 99:7652-7657.

Qian, W., Jia, Y., Ren, S. X., He, Y. Q., Feng, J. X., Lu, L. F., Sun, Q., Ying, G., Tang, D. J., Tang, H., Wu, W., Hao, P., Wang, L., Jiang, B. L., Zeng, S., Gu, W. Y., Lu, G, Rong, L., Tian, Y., Yao, Z., Fu, G., Chen, B., Fang, R., Qiang, B., Chen, Z., Zhao, G. P., Tang, J. L., and He, C. 2005. Comparative and functional genomic analyses of the pathogenicity of phytopathogen Xanthomonas campestris pv. campestris. Genome Res. 15:757767.

Roden, J. A., Belt, B., Ross, J. B., Tachibana, T., Vargas, J., and Mudgett, M. B. 2004. A genetic screen to isolate type III effectors translocated into pepper cells during Xanthomonas infection. Proc. Natl. Acad. Sci. U.S.A. 101:16624-16629.

Sambrook, J., Fritsch, E. F., and Maniatis, T. 1989. Molecular Cloning: A Laboratory Manual, 2nd ed. Cold Spring Harbor Laboratory, Cold Spring Harbor, NY, U.S.A.

Schafer, A., Tauch, A., Jager, W., Kalinowski, J., Thierbach, G., and Puhler, A. 1994. Small mobilizable multi-purpose cloning vectors de- rived from the Escherichia coli plasmids pK18 and pK19: Selection of defined deletions in the chromosome of Corynebacterium glutamicum. Gene 145:69-73.

Schechter, L. M., Roberts, K. A., Jamir, Y., Alfano, J. R., and Collmer, A. 2004. Pseudomonas syringae type III secretion system targeting signals and novel effectors studied with a Cya translocation reporter. J. Bacteriol. 186:543-555.

Schechter, L. M., Vencato, M., Jordan, K. L., Schneider, S. E., Schneider D. J., and Collmer, A. 2006. Multiple approaches to a complete inventory of Pseudomonas syringae pv. tomato DC3000 type III secretion system effector proteins. Mol. Plant-Microbe Interact. 19:1180-1192.

Tang, D. J., He, Y. Q., Feng, J. X., He, B. R., Jiang, B. L., Lu, G. T., Chen, B., and Tang, J. L. 2005. Xanthomonas campestris pv. campestris possesses a single gluconeogenic pathway that is required for virulence. $\mathrm{J}$. Bacteriol. 187:6231-6237.

Thieme, F., Szczesny, R., Urban, A., Kirchner, O., Hause, G., and Bonas, U. 2007. New type III effectors from Xanthomonas campestris pv. vesicatoria trigger plant reactions dependent on a conserved N-myristoylation motif. Mol. Plant-Microbe Interact. 20:1250-1261.

Tsuge, S., Terashima, S., Furutani, A., Ochiai, H., Oku, T., Tsuno, K., Kaku, H., and Kubo, Y. 2005. Effects on promoter activity of base substitutions in the cis-acting regulatory element of HrpXo regulons in Xanthomonas oryzae pv. oryzae. J. Bacteriol. 187:2308-2314.

Turner, P., Barber, C. E., and Daniels, M. J. 1985. Evidence for clustered pathogenicity genes in Xanthomonas campestris pv. campestris. Mol. Gen. Genet. 199:338-343.

Vencato, M., Tian, T., Alfano, J. R., Buell, C. R., Cartinhour, S., DeClerk, J., Guttman, D. S., Joardar, V., Lindeberg, M., Bronstein, P. A., Mansfield, J., Myers, C. R., Collmer, A., and Schneider, D. J. 2006. Bioinformatics-enabled identification of the HrpL regulon and type III secretion system effector proteins of Pseudomonas syringae pv. phaseolicola 1448A. Mol. Plant-Microbe Interact. 19:1193-1206.

Vinatzer, B. A., Jelenska, J., and Greenberg, J. T. 2005. Bioinformatics correctly identifies many type III secretion substrates in the plant pathogen Pseudomonas syringae and the biocontrol isolate $P$. fluorescens SBW25. Mol. Plant-Microbe Interact. 18:877-888.

Vorhölter F. J., Schneiker, S., Goesmann, A., Krause, L., Bekel, T., Kaiser, O., Linke, B., Patschkowski, T., Rückert, C., Schmid, J., Sidhu, V. K., Sieber, V., Tauch, A., Watt, S. A., Weisshaar, B., Becker, A., Niehaus, K., and Pühler, A. 2008. The genome of Xanthomonas campestris pv. campestris B100 and its use for the reconstruction of metabolic pathways involved in xanthan biosynthesis. J. Biotechnol. 134:33-45.

Wei, C. F., Kvitko, B. H., Shimizu, R., Crabill, E., Alfano, J. R., Lin, N. C., Martin, G. B., Huang, H. C., and Collmer, A. 2007a. A Pseudomonas syringae pv. tomato DC3000 mutant lacking the type III effector HopQ1-1 is able to cause disease in the model plant Nicotiana benthamiana. Plant J. 51:32-46.

Wei, K., Tang, D. J., He, Y. Q., Feng, J. X., Jiang, B. L., Lu, G. T., Chen, B., and Tang, J. L. 2007b. hpaR, a putative marR family transcriptional regulator, is positively controlled by $\mathrm{HrpG}$ and $\mathrm{HrpX}$ and involved in the pathogenesis, hypersensitive response, and extracellular protease production of Xanthomonas campestris pathovar campestris. J. Bacteriol. 189:2055-2062.

Wengelnik, K., and Bonas, U. 1996. HrpXv, an AraC-type regulator, activates expression of five of the six loci in the hrp cluster of Xanthomonas campestris pv. vesicatoria. J. Bacteriol. 178:3462-3469.

Wengelnik, K., Van den Ackerveken, G., and Bonas, U. 1996. HrpG, a key hrp regulatory protein of Xanthomonas campestris pv. vesicatoria is homologous to two-component response regulators. Mol. Plant-Microbe Interact. 9:704-712.

Windgassen, M., Urban, A., and Jaeger, K. E. 2000. Rapid gene inactivation in Pseudomonas aeruginosa. FEMS (Fed. Eur. Microbiol. Soc.) Microbiol. Lett. 193:201-205.

Xu, R. Q., Blanvillain, S., Feng, J. X., Jiang, B. L., Li, X. Z., Wei, H. Y., Kroj, T., Lauber, E., Roby, D., Chen, B., He, Y. Q., Lu, G. T., Tang, D. J., Vasse, J., Arlat, M., and Tang, J. L. 2008. AvrAC ${ }_{\mathrm{Xcc8004}}$, a type III effector with a leucine rich repeat domain from Xanthomonas campestris pathovar campestris confers avirulence in vascular tissues of the Arabidopsis thaliana ecotype Col-0. J. Bacteriol. 190:343-355.

Yanisch-Perron, C., Vieira, J., and Messing, J. 1985. Improved M13 phage cloning vectors and host strains: Nucleotide sequences of the M13mp18 and pUC19 vectors. Gene 33:103-119.

\section{AUTHOR-RECOMMENDED INTERNET RESOURCES}

National Center for Biotechnology Information BLAST server:, www.ncbi.nlm.nih.gov/

3D-PSSM website: www.sbg.bio.ic.ac.uk/ 3dpssm 